\title{
Are Entrepreneurs Optimistic Concerning Institutional Constraints? Evidence from a Balkan Country
}

\author{
Gentjan Çera* and Edmond Çera
}

Department of Business Administration, Faculty of Management and Economics, Tomas Bata University in Zlin, Mostní 5139, 76001 Zlín, Czech Republic

*Corresponding author

\begin{abstract}
A considerable number of empirical studies have shown that institutions have the capacity to shape business behaviour. Formal and informal institutions might enable or constrain business activity. The aim of this research is to explore whether an entrepreneur's perception of institutional constraints differs in time (present versus future). By comparing these two positions, we can see how optimistic are entrepreneurs. The research is anchored at the institutional theory. The analysis is conducted on firm-level data collected through a faceto-face survey. The sample size consists of 391 firms operating in a Balkan country, Albania. The non-parametric chi-square test for independence was performed in two stages: firstly, between institutional constraints and both current and future business climate; secondly, only the favourable category of both business climates and institutional constraints. The selected institutional constraints analysed are informal institutions (corruption and informal competition) and formal ones (courts and road infrastructure). Findings of this paper are useful to get a better view of the nature of entrepreneurs' behaviour in a Balkan country. The nonparametric test revealed insignificant differences between the favourable category of both current and future business climate across the institutional constraints' levels. Consequently, the entrepreneurs' perception on institutional constraints will not change in the future, so, they will be neither optimistic nor pessimistic. The generalisation of these results to another context is limited, even though concerning regional, economic and institutional environments Albania has similarities with other transition and in particular with Balkan countries. This study offers insights for scholars dealing with institutional transformation and business environment, and it adds value to the knowledge on transition countries, in particular on the Albanian case.
\end{abstract}

Keywords: Albania; entrepreneurship; institutional constraints; non-parametric methods; transition country.

\section{Introduction}

Entrepreneurial activity makes a vital contribution to economic development (Bosma, Content, Sanders, \& Stam, 2018), reduce the unemployment rate and increase the competitiveness (Chowdhury, Audretsch, \& Belitski, 2018). On the other hand, firm growth is determined even by the business environment (Xheneti \& Bartlett, 2012). Firm growth leads to 
the development of productivity by improving technology and investment by enhancing business activity (Dethier, Hirn, \& Straub, 2011). Accordingly, it can be assumed an association between institutional environment and business climate.

According to the institutional theory developed by North (1990), institutions have the strength to shape firm behaviour. Instructions are divided into formal and informal institutions. Both, type of institutions might constraint or enable entrepreneurship. Formal institutions consist of rules communicated through certified channels, usually public. They are originated from policy and regulatory framework. To contrast, informal institutions consist of unwritten rules that are not communicated through official channels. They are seen as a product of values and cultural norms manifested in a society (North, 1990). In the current research, courts and road infrastructure are part of formal institutions, whereas corruption and informal competition belong to informal institutions.

Though vast empirical studies focused on the relationship between institutional constraints and entrepreneurship, yet it is not clear enough whether business constraints influence an entrepreneur's perception for the future. This paper aims to investigate the association of selected institutional constraints and the entrepreneur's perception on the business climate in the case of Albania. By doing so, we may explore whether entrepreneurs are optimistic about their future activity. To our best knowledge, there is no secondary data available for Albania informing for the level of entrepreneurship indicators. This study aims to fill this gap by exploring the association between institutional constraints and current and future business climate in the context of Albania.

The remaining part of this paper is structured as follows: the second part is dedicated to the entrepreneurship in the Balkans; the third part deals with research method applied; the results are presented in section four, and the concluding remarks are dealt offered in section five.

\section{Entrepreneurship in the Balkans}

\subsection{General view}

At the beginnings of the 1990s, the Balkans countries changed the economical institution from controlled to market-oriented economy. Countries located in the Balkan Peninsula like Albania decided to privatise the state-owned enterprises and liberalization of prices, expecting that economic agents will be integrated in the new economic mindset. These countries expected a fast transition from centralized to free market economy (Ramadani \& Dana, 2013). During the first years of the transition, entrepreneurs did not have any clue how to deal in a new reality, which Dana (1996) named it as "prevailing chaos". Economic models imported from western countries were applied as such, without paying attention to the economic, political and institutional environment in the Balkans. These models were not giving the expected results. Balkan countries like Albania were transforming the whole system, which led to the transformation of individual values and perspectives. The limited know-how related to the behaviour of individuals in a market-oriented economy was attributed to the practices of 
controlled economies (Dana, 2011; Ramadani \& Dana, 2013). Even nowadays, the business culture is not consolidated among countries in Balkan, as compared to advanced countries.

Balkan countries like Albania were introduced with new challenges particularly in the field of entrepreneurship because it was needed to build capacity for individuals in terms of abilities, skills and actions in a new environment that changes quickly. The ways how a government could affect entrepreneurship are totally different, as compared to the communist period when the economy was controlled (Dana, 2011). Weak institutions among these countries led to that type of entrepreneurship often forced to operate in unfair and informal competition. Moreover, the size of the parallel economy and the level of corruption reached high figures across Eastern Europe (Ramadani \& Schneider, 2013). "Informal economic activity can take the form of an impromptu stall or itinerant vending. Unrecorded cash sales circumvent taxation as well as regulation. The law is often bent, but authorities generally tolerate the sector" (Ramadani \& Dana, 2013, p. 221).

Even almost three decades from the time when transition started, yet nowadays the educational system exhibits some characteristics originated from the communist system (Aaltio, 2008). Therefore, it is difficult to implement the new entrepreneurial mindset, as modern educational curricula are needed to be employed. In a market-opened economy, the insecurity of jobs is a permanent concern for both individuals and policymakers. In this regards, the educational system should equip individuals with adequate abilities and skills that help to succeed in the future. Skills and abilities, which are considered unnecessary in advance economies, might be useful in transition countries, including Balkans countries like Albania (Ramadani \& Schneider, 2013).

Recently, the Balkans are facing difficulties originated from the high rates of unemployment among the young generation. In these circumstances, they preferred to emigrate to more developed economies and to build their life there. To solve these problems, the formation of SMEs could be seen as a way to reduce the unemployment rate and fostering the economy (Palalić, Ramadani, Đilović, Dizdarević, \& Ratten, 2017; Ramadani et al., 2019).

\subsection{Albanian context}

Entrepreneurial activity is one of the key factors that affect the readjustment of the Albanian economy. Reports offer information concerning this effect. Small and medium-size enterprises that operate in Albania produce sixty-seven per cent of the value-added and eighty per cent of employment (European Commission, 2017). These numbers are very meaningfully when compared to the average of EU proportions: fifty-seven per cent of the value-added and sixtyseven of employment (see Figure 1). Accordingly, boosting entrepreneurship is vital for Balkan countries like Albania. The share of SMEs in Albania is 99.8\%, reflecting the same figure even in the case of EU. 
Figure 1: Business demography indicators in Albania

\begin{tabular}{|c|c|c|c|c|c|c|c|c|c|}
\hline \multirow[t]{3}{*}{ Class size } & \multicolumn{3}{|c|}{ Number of enterprises } & \multicolumn{3}{|c|}{ Number of persons employed } & \multicolumn{3}{|c|}{ Value added } \\
\hline & \multicolumn{2}{|c|}{ Albania } & \multirow{2}{*}{\begin{tabular}{|c|}
$E U$ \\
Share
\end{tabular}} & \multicolumn{2}{|c|}{ Albania } & \multirow{2}{*}{\begin{tabular}{c|}
$E U$ \\
Share
\end{tabular}} & \multicolumn{2}{|c|}{ Albania } & \multirow{2}{*}{$\begin{array}{c}E U \\
\text { Share }\end{array}$} \\
\hline & Number & Share & & Number & Share & & Million $€$ & Share & \\
\hline Micro & 87854 & $94.5 \%$ & $93.0 \%$ & 162621 & $40.8 \%$ & $29.8 \%$ & 95250 & $21.9 \%$ & $20.9 \%$ \\
\hline Small & 4105 & $4.4 \%$ & $5.8 \%$ & 79713 & $20.0 \%$ & $20.0 \%$ & 105294 & $24.2 \%$ & $17.8 \%$ \\
\hline $\begin{array}{l}\text { Medium- } \\
\text { sized }\end{array}$ & 833 & $0.9 \%$ & $0.9 \%$ & 82650 & $20.7 \%$ & $16.7 \%$ & 89397 & $20.5 \%$ & $18.2 \%$ \\
\hline SMEs & 92792 & $99.9 \%$ & $99.8 \%$ & 324984 & $81.6 \%$ & $66.6 \%$ & 289940 & $66.6 \%$ & $56.8 \%$ \\
\hline Large & 128 & $0.1 \%$ & $0.2 \%$ & 73523 & $18.4 \%$ & $33.4 \%$ & 145479 & $33.4 \%$ & $42.9 \%$ \\
\hline Total & 92920 & $100.0 \%$ & $100.0 \%$ & 398507 & $100.0 \%$ & $100.0 \%$ & 435419 & $100.0 \%$ & $100.0 \%$ \\
\hline
\end{tabular}

Source: European Commission $(2017$, p. 2)

According to a report from OECD (2016), Albania has progressed in terms of the institutional, regulatory and operational environment for SMEs development. It is adopted the Business Investment and Development Strategy for 2014-2020, which frameworks some vital policy objectives. A positive impact is expected on entrepreneurship if this strategy is successfully applied.

One of the main constraints for business activity is access to finance. Based on the same report from OECD, access to finance remains problematic in Albania (see Figure 2). As mention earlier, this is even due to high levels of a parallel economy characterized as unfair or informal competition. However, bank lending is the main source for getting funds or financing business projects, whereas other options like factoring are still underdeveloped.

Another progress that Albania has made is related to the inclusion of entrepreneurship education into key national policy. Nevertheless, compared to previous years, Albania scored regress in women's entrepreneurship. But, this could be due to a new employed methodology to calculate the indicators of this dimension (OECD, 2016).

Marginal advancement has been made in designing the framework for business support and innovation policy since previous assessment back in 2012. It is required from government to adopt its strategy for innovation, and paying attention to the developing the necessary infrastructure to encourage innovation within firms, as well as applying the triple helix theory which connects government, academia and industry (Kim, Kim, \& Yang, 2012). Even though there are introduced some strategies pointing at general environmental for economic improvement, none of the policy frameworks clearly target SMEs. This lack of policies targeting the greening of SMEs means no financial or regulatory incentives are in place (OECD, 2016). 
Figure 2: Small Business Act draft scores for Albania

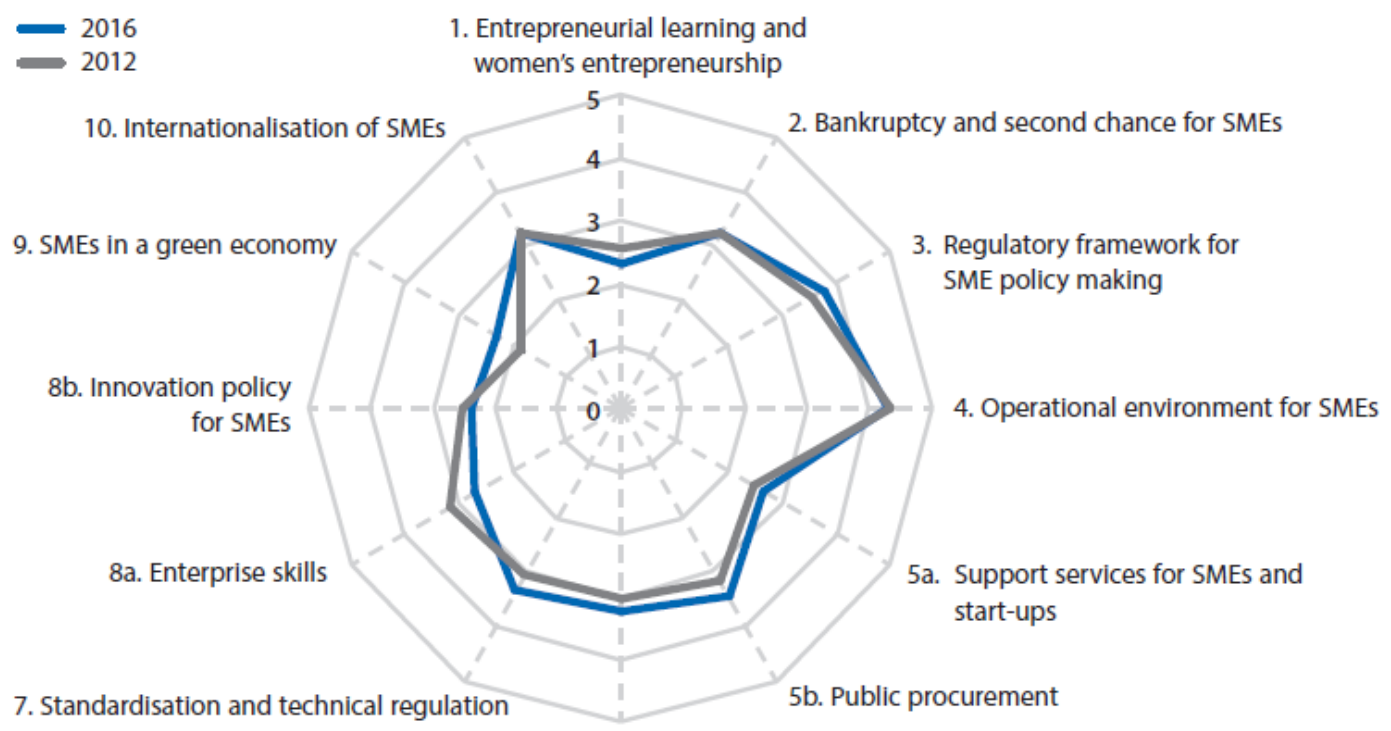

6. Access to finance for SMEs

Source: $\operatorname{OECD}(2016, p .212)$

Concerning the issues related to exports, based on what the report from OECD (2016) pointed, regulatory barriers to trade remain a major obstacle to advance development. Even though costs are somewhat low, the time needed to export and import, as well as the number of documents needed, are considered to be at a high level.

Taking into consideration all the above discussion, it is a need to investigate whether entrepreneurs will be optimists or pessimists for the future. To do this, it is required to explore the institutional constraints of the business activity. Thus, a deep analysis would shed light on these issues.

\section{Research method}

\subsection{Variable measurement}

As mentioned earlier, the paper aims to investigate whether entrepreneurs are or not optimistic about the level of institutional constraints in the future. This can be achieved by exploring the association between selected business institutional constraints and current and future business climate. The current business climate is measured by a single question, which was: "While taking into consideration the current half year, how would you evaluate the current situation for your firm?" Similar, the future business climate was measured by this question: "While taking into consideration the coming second half of the year, how would you evaluate 
the situation of your firm?" Both of them had the same possible responses were: 1 'unfavourable', 2 - 'normal', and 3 - 'favourable'.

Institutional constraints were represented by the following constraints: courts, road infrastructure, corruption and informal competition. Firms were asked to hold a position per each item, by answering the following question: Please, evaluate to what extent each of the listed statements poses a problem for your business. Subjects had to choose one option between these responses: 1 - 'Is not a problem', 2 - 'Minor problem', 3 - 'Moderate problem', 4 'Major problem', and 5 - 'Severe problem'. For the purposes of obtaining robust results that do not violent any statistical assumption, the measurement type of these constraints were transformed into: 1 - 'Not a problem or minor one' including two first categories of previous measurement 'Is not a problem' and 'Minor problem'; 2 - 'Moderate problem' which represent the same category in the previous measurement; and 3 - 'Major or severe problem', combining last categories 'Major problem' and 'Sever problem'.

\subsection{Statistical test}

The non-parametric chi-square test of independence was employed in two steps. Firstly, it was performed to check the association between institutional constraints and both current and future business climate. By doing so we investigate whether the association between these variables is present or not, and then by comparing the significances between current and future business climate we can see whether it is any difference in the perception of the institutional constraints or not. Secondly, the chi-square test of independence was employed between institutional constraints and current and future business climate only for the favourable level. This step offers information on whether the favourable level in both business climate differs among levels of institutional constraints. If we prove this, that we have found statistically significant differences between two points in time: current and future. Then, if the future business climate reflected higher levels than the current one, we conclude that entrepreneurs are optimistic on a certain intuitional constraint.

Chi-square test of independence compares the observed frequencies of cases that occur in each of the categories, with the values that would be expected if there was no association between the two variables being measured (Gravetter \& Wallnau, 2017).

\subsection{Data}

The data are collected through a survey administrated in Albania. The sample distribution is a representation of all businesses in the country in terms of region and industry type. Overall, 391 firms successfully filled in the questionnaire. More than half of the questionnaires $(57.9 \%)$ were collected in the capital city, about $23 \%$ of the interviews in South region, $11 \%$ in the central region and the rest were collected in the north region. Referring to the industry type, about $20 \%$ of the firms were under manufacture industry, $40 \%$ of them in service and $40 \%$ were under the trade sector. 


\section{Results}

Pearson chi-square test revealed that between entrepreneur's perception on corruption and business climate is a significant association. Table 1 provides the results of Pearson chi-square test for the association of corruption and both current and future business climate. Preliminary checks were performed to check for the assumptions of the test and they reported no violation. In case of current business climate, chi-square test showed that business climate categories were significantly different on corruption levels, $\chi^{2}(4, n=377)=17.08, p=0.002$. Moreover, similar results are reported even between future business climate and corruption, $\chi^{2}(4, n=377)=19.02$, $p=0.001$. Now we are interested to know whether is any statistical differences between the entrepreneur's perception on corruption and the favourable categories of current and future business climate (last row in Table 1). The applied chi-square test found no statistically difference between them, $\chi^{2}(n=118)=0.029, p=0.985$. Based on these statistical results, it can be concluded that entrepreneurs will not change in the future their perception on corruption and business climate. Therefore, there was no improvement in their perception on corruption from current to the future business climate.

Table 1. Results of chi-square tests for corruption

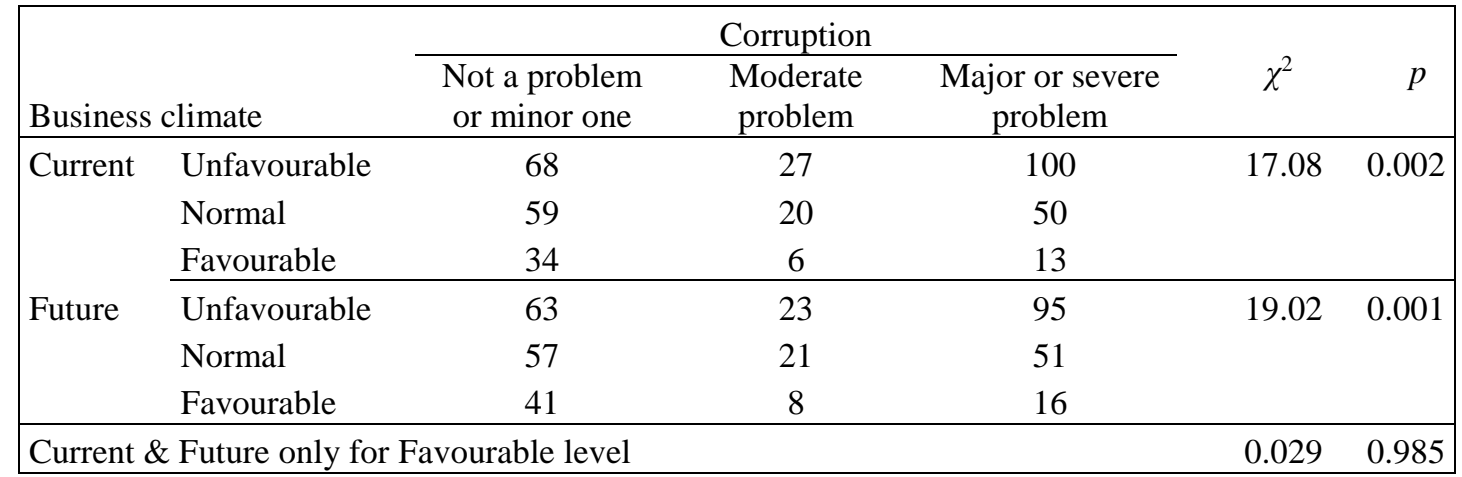

In Table 2 are summarised the results of chi-square test for the association of informal competition and both current and future business climate. No violation of the assumptions of the statistical test were reported. In case of current business climate, chi-square test revealed that informal competition levels were significantly different on business climate categories, $\chi^{2}(4, n=391)=6.862, p=0.143$. On the other hand, the same results are reported even between future business climate and informal competition, $\chi^{2}(4, n=390)=1.362, p=0.851$. Turning back to the main interest to find whether is any statistical differences between the entrepreneur's perception on informal competition and the favourable categories of current and future business climate (last row in Table 2). The performed chi-square test showed that there was insignificant difference between them, $\chi^{2}(n=122)=0.419, p=0.811$. According to these obtained results, it can be said that entrepreneurs will not change in the future their perception on informal competition and business climate. Consequently, there was no improvement in their perception on informal competition from current business climate to the future one. 
Table 2. Results of chi-square tests for informal competition

\begin{tabular}{|c|c|c|c|c|c|c|}
\hline \multirow{2}{*}{\multicolumn{2}{|c|}{ Business climate }} & \multicolumn{3}{|c|}{ Informal competition } & \multirow[b]{2}{*}{$\chi^{2}$} & \multirow[b]{2}{*}{$p$} \\
\hline & & $\begin{array}{l}\text { Not a problem } \\
\text { or minor one }\end{array}$ & $\begin{array}{l}\text { Moderate } \\
\text { problem }\end{array}$ & $\begin{array}{c}\text { Major or severe } \\
\text { problem }\end{array}$ & & \\
\hline \multirow[t]{3}{*}{ Current } & Unfavourable & 46 & 21 & 133 & 6.862 & 0.143 \\
\hline & Normal & 25 & 23 & 88 & & \\
\hline & Favourable & 15 & 11 & 29 & & \\
\hline \multirow[t]{3}{*}{ Future } & Unfavourable & 42 & 24 & 119 & 1.362 & 0.851 \\
\hline & Normal & 28 & 20 & 90 & & \\
\hline & Favourable & 17 & 11 & 39 & & \\
\hline \multicolumn{5}{|c|}{ Current \& Future only for Favourable level } & 0.419 & 0.811 \\
\hline
\end{tabular}

In Table 3 are shown the results of chi-square test for the association of entrepreneur's perception on courts and both current and future business climate. No violation of the assumptions of the statistical test was reported. In the case of current business climate, this test demonstrated that the association between entrepreneur's perception on courts and business climate categories were not significantly different, $\chi^{2}(4, n=321)=7.623, p=0.106$. The same results were found even between future business climate and entrepreneur's perception on courts, $\chi^{2}(4, n=321)=4.280, p=0.369$. Going back to the main aim of the study - exploring whether is any statistical differences between entrepreneur's perception on courts and the favourable categories of current and future business climate (last row in Table 3). The performed chi-square test showed that there was no statistical significant difference between them, $\chi^{2}(n=106)=0.089, p=0.956$. With these statistical results in mind, it can be seen that entrepreneurs will not change in the future their perception on courts and business climate. Thus, no improvement was noticed in their perception on courts from current to the future business climate.

Table 3. Results of chi-square tests for courts

\begin{tabular}{|c|c|c|c|c|c|c|}
\hline \multirow{2}{*}{\multicolumn{2}{|c|}{ Business climate }} & \multicolumn{3}{|c|}{ Courts } & \multirow[b]{2}{*}{$\chi^{2}$} & \multirow[b]{2}{*}{$p$} \\
\hline & & $\begin{array}{l}\text { Not a problem } \\
\text { or minor one }\end{array}$ & $\begin{array}{c}\text { Moderate } \\
\text { problem }\end{array}$ & $\begin{array}{c}\text { Major or severe } \\
\text { problem }\end{array}$ & & \\
\hline \multirow[t]{3}{*}{ Current } & Unfavourable & 93 & 14 & 52 & 7.623 & 0.106 \\
\hline & Normal & 57 & 17 & 38 & & \\
\hline & Favourable & 33 & 8 & 9 & & \\
\hline \multirow[t]{3}{*}{ Future } & Unfavourable & 81 & 15 & 48 & 4.280 & 0.369 \\
\hline & Normal & 66 & 16 & 39 & & \\
\hline & Favourable & 37 & 8 & 11 & & \\
\hline \multicolumn{4}{|c|}{ Current \& Future only for Favourable level } & & 0.089 & 0.956 \\
\hline
\end{tabular}


Table 4 shows the results of chi-square test for the association between an entrepreneur's perception on road infrastructure and both current and future business climate. Preliminary checks were done to check for the validity of assumptions of the test and they showed no violation. In the case of current business climate, this test demonstrated that the association between entrepreneur's perception on road infrastructure and business climate categories were not significantly different, $\chi^{2}(4, n=388)=5.999, p=0.199$. Similar results were noticed even between future business climate and entrepreneur's perception on road infrastructure, $\chi^{2}(4, n=$ $387)=4.026, p=0.403$. Turning back to the main aim of the study which is to identify whether is any statistical differences between entrepreneur's perception on road infrastructure and the favourable categories of both current and future business climate (last row in Table 4). The applied chi-square test revealed that there was no statistical significant difference between them, $\chi^{2}(n=122)=0.336, p=0.846$. Considering these results, it can be seen that entrepreneurs will not change their perception on courts in the future. As a result, no improvement in their perception on road infrastructure was noticed from current to the future business climate.

Table 4. Results of Chi-square tests for road infrastructure

\begin{tabular}{|c|c|c|c|c|c|c|}
\hline \multirow{2}{*}{\multicolumn{2}{|c|}{ Business climate }} & \multicolumn{3}{|c|}{ Road infrastructure } & \multirow[b]{2}{*}{$\chi^{2}$} & \multirow[b]{2}{*}{$p$} \\
\hline & & $\begin{array}{l}\text { Not a problem } \\
\text { or minor one }\end{array}$ & $\begin{array}{l}\text { Moderate } \\
\text { problem }\end{array}$ & $\begin{array}{c}\text { Major or severe } \\
\text { problem }\end{array}$ & & \\
\hline \multirow[t]{3}{*}{ Current } & Unfavourable & 76 & 37 & 86 & 5.999 & 0.199 \\
\hline & Normal & 59 & 32 & 42 & & \\
\hline & Favourable & 24 & 8 & 24 & & \\
\hline \multirow[t]{3}{*}{ Future } & Unfavourable & 71 & 36 & 79 & 4.026 & 0.403 \\
\hline & Normal & 62 & 30 & 43 & & \\
\hline & Favourable & 27 & 12 & 27 & & \\
\hline \multicolumn{4}{|c|}{ Current \& Future only for Favourable level } & & 0.336 & 0.846 \\
\hline
\end{tabular}

\section{Concluding remarks}

The study takes an institutional perspective (North, 1990) and aims to find whether entrepreneurs are optimistic for the future considering some business constraints. This requires first to explore the associations between institutions and business behaviour (Çera \& Çera, 2018). The selected institutions in this paper are: courts, road infrastructures, corruption and unfair and/or informal competition.

This research revealed that the entrepreneurs operating in Albania are neither optimistic nor pessimistic concerning the effect of institutions on their business activity. The non-parametric method proofed that there is no difference between two favourable levels of business climates and selected constraints.

Scholars and policymakers consider the entrepreneurial activity as a vital component regarding which tools can stimulate economic development and create new jobs (Chowdhury et al., 2018). In this regard, developed countries have established policies which aim at 
stimulating entrepreneurship. However, the role of business policies in fostering entrepreneurial activity differs across countries because of the variations in regional, economic and political environments. The current research aims just to explore whether entrepreneurs are optimistic about the future concerning the business institutional constraints in the context of a Balkan country like Albania.

Though this study has reached its aims, still there are limitations in research. The results are limited to a Balkan country like Albania, which may reflect similar conditions in economic, political and institutional environments with limited countries.

Findings from the analysis carried out here indicated that businesses are not optimistic, this could be useful for policymakers as a means of amending or improving the current state of policies aimed at entrepreneurship. By doing so will lead to the improvement of the general business environment. Taking all together, this paper contributes to the existing body of literature on entrepreneurship.

\section{Acknowledgement}

This research was supported by the Internal Grant Agency of Tomas Bata University, under Grant IGA/FaME/2019/002, title "The role of institutional environment in fostering entrepreneurship".

\section{References}

Aaltio, I. (2008). Management education as an identity construction: the case of Estonia and its transition economy background. International Journal of Entrepreneurship and Small Business, 5(1), 83-99. https://doi.org/10.1504/IJESB.2008.015955

Bosma, N., Content, J., Sanders, M., \& Stam, E. (2018). Institutions, entrepreneurship, and economic growth in Europe. Small Business Economics, 51(2), 483-499. https://doi.org/10.1007/s11187-018-0012-x

Brixiova, Z., \& Égert, B. (2017). Entrepreneurship, institutions and skills in low-income countries. $\quad$ Economic Modelling, 67, 381-391. https://doi.org/10.1016/J.ECONMOD.2017.02.020

Brixiová, Z., \& Égert, B. (2012). Business environment, start-ups, and productivity during transition. Macroeconomic Dynamics, 16(S2), 213-231. https://doi.org/10.1017/S1365100511000344

Čadil, J., Mirošník, K., \& Rehák, J. (2017). The lack of short-term impact of cohesion policy on the competitiveness of SMEs. International Small Business Journal: Researching Entrepreneurship, 35(8), 991-1009. https://doi.org/10.1177/0266242617695382

Çera, G., \& Çera, E. (2018). Is business' perception on selected formal and informal institutions affected by the business climate? In Economic and Social Development: Book of 
Proceedings (pp. 246-254). Lisbon: Varazdin.

Chowdhury, F., Audretsch, D. B., \& Belitski, M. (2018). Institutions and Entrepreneurship Quality. Entrepreneurship Theory and Practice, 1-31. https://doi.org/10.1177/1042258718780431

Dana, L. P. (1996). Albania in the twilight zone: The perseritje model and its impact on small business. Journal of Small Business Management, 34(1), 64-70.

Dana, L. P. (2011). When economies change hands: a survey of entrepreneurship in the emerging markets of Europe from the Balkans to the Baltic states. New York, NY: Routledge.

Dethier, J.-J., Hirn, M., \& Straub, S. (2011). Explaining Enterprise Performance in Developing Countries with Business Climate Survey Data. The World Bank Research Observer, 26(2), 258-309. https://doi.org/10.1093/wbro/lkq007

European Commission. (2017). European Neighbourhood Policy and Enlargement Negotiations: 2017 SBA Fact Sheet Albania. Brussel.

Gravetter, F. J., \& Wallnau, L. B. (2017). Statistics for the behavioral sciences (10th ed.). CENGAGE Learning.

Kim, Y., Kim, W., \& Yang, T. (2012). The effect of the triple helix system and habitat on regional entrepreneurship: Empirical evidence from the U.S. Research Policy, 41(1), 154166. https://doi.org/10.1016/J.RESPOL.2011.08.003

Krasniqi, B. A., \& Desai, S. (2016). Institutional drivers of high-growth firms: country-level evidence from 26 transition economies. Small Business Economics, 47(4), 1075-1094. https://doi.org/10.1007/s11187-016-9736-7

North, D. C. (1990). Institutions, institutional change, and economic performance. Cambridge University Press.

OECD. (2016). SME Policy Index: Western Balkans and Turkey 2016: Assessing the Implementation of the Small Business Act for Europe. https://doi.org/10.1787/9789264254473-en

Palalić, R., Ramadani, V., Đilović, A., Dizdarević, A., \& Ratten, V. (2017). Entrepreneurial intentions of university students: a case-based study. Journal of Enterprising Communities: People and Places in the Global Economy, 11(3), 393-413. https://doi.org/10.1108/JEC-12-2016-0046

Ramadani, V., \& Dana, L.-P. (2013). The State of Entrepreneurship in the Balkans: Evidence from Selected Countries. In Entrepreneurship in the Balkans (pp. 217-250). Berlin, Heidelberg: Springer Berlin Heidelberg. https://doi.org/10.1007/978-3-642-36577-5_12

Ramadani, V., Hisrich, R. D., Abazi-Alili, H., Dana, L.-P., Panthi, L., \& Abazi-Bexheti, L. (2019). Product innovation and firm performance in transition economies: A multi-stage estimation approach. Technological Forecasting and Social Change, 140, 271-280. 
https://doi.org/10.1016/J.TECHFORE.2018.12.010

Ramadani, V., \& Schneider, R. C. (Eds.). (2013). Entrepreneurship in the Balkans. Berlin, Heidelberg: Springer Berlin Heidelberg. https://doi.org/10.1007/978-3-642-36577-5

Xheneti, M., \& Bartlett, W. (2012). Institutional constraints and SME growth in postcommunist Albania. Journal of Small Business and Enterprise Development, 19(4), 607626. https://doi.org/10.1108/14626001211277424 